\title{
Cultural Views of a Society Through Taylor Swift's Song
}

\author{
Daniel Ginting \\ daniel.ginting@machung.ac.id \\ Eldana Reza Levana \\ 211710009@student.machung.ac.id
}

\author{
Universitas Ma Chung
}

\begin{abstract}
Songs as cultural products function to help people to fulfil their needs. When people listen to the songs, they both enjoy the melody and also lyrics of the songs. Songs serve as tools to achieve different essential objectives such as changing moods, relating, and shaping their own identity. In this research, the writer studies deixis in song lyrics from the selected song in Taylor Swift's Folklore album: Cardigan, the Last Great American Dynasty, August, Illicit Affairs, and Betty. The analysis deixis of this study reveals a variety of life issues is treated directly or is strongly involved in the content of the lyrics of songs. This study found that lyrics have undergone dramatic changes when the influence of other cultures is unavoidable. This is an issue of significant interest and concern for parents and educators.
\end{abstract}

Keywords: Meaning; Lyrics; Deixis; Society

\section{INTRODUCTION}

Songs as cultural products function to help people to fulfil their needs. For songwriters, songs are not only intended to entertain their listeners but also to convey messages such as feelings, perspectives, ideas etc. Bull (2011) mentions that lyrics are parts of discourse that consists of words and sentences with different grammatical functions. When people listen to the songs, they both enjoy the melody and also lyrics of the songs. To young generation, for example, songs occupy a very important space in their lives (Campo, 2020) such as from altering moods, shaping aspects related to personal identity to strengthening interpersonal relationships. It is also one of the tools most used by teenagers in their daily lives to achieve different essential objectives such as changing moods, relating, and shaping their own identity (Oriola \& Gustems, 2015). Music plays an important part in configurating the adolescent personality (Miranda, 2012). Moreover, songs are believed to have varying effects on a person's mental state (Evans \& Schubert, 2008; Gabrielsson, 2011). It was also found that listening to music causes certain changes in people's mental state depending on the music genre one listens to (Juslin, 2011). A study by Ruud (2013) contested the existence of "therapeutic music" which, allegedly, has the potency to improve the listeners' health. 
Songs are composed of linguistic properties whose meanings are occupied in the lyrics. In the songs, deictical expressions are very commonly found. Yule (1996) states deixis is one of the essential aspects of the technical term of utterances. The word 'deixis' is borrowed from the Greek word for pointing, reference, or indicating. Levinson in R. \& Ward (2004) suggests, deixis directly concerns the relationship language and context, which is reflected in structures of language themselves. Nevertheless, the meanings of those expressions are not always easily identified if people have no context to base on their interpretation. As a result, the absence of the context is likely to result in either confusion or misunderstanding.

Deictical issues have attracted numerous researchers. Natalia \& Santoso (2020) have studied deixis in the song lyrics by Rhoma Irama. They have found that personal deixis such as aku, daku, $\mathrm{ku}, \mathrm{amu}, \mathrm{mu}$, and nya is dominating all types of deixis, Hidayah (2019) has studied the Selena Gomez's song lyrics Back To You. She has found that the songwriters have used all types of deixis. Most of the personal deixis in Back To You song lyric refers to the speaker itself which are encoded by first singular person deixis like I and my. While for first plural person deixis, which is we mostly refer to the speaker. Sitorus (2019) has investigated the kinds of deixis and the dominant deixis in song lyrics "You are the Reason" by Calum Scott. Using a qualitative research, he found three kinds of deixis in the song: person (it, these, those books, I, you, we, your, our, t heir), spatial (here, there, close to) and temporal deixis (now, soon, lately, recently, ago, today, tomorrow, yesterday).

This article focuses on the works of Taylor Alison Swift. As a well-known influential American singer with numerous achievements (Grammy Awards), Taylor Swift is a figure worthy of study. She is one of the best-selling artists of all time, having sold more than 40 million albums - including 27.1 million in the US — and 130 million single downloads (Gordon, 2017). Apart from music, Swift has also played supporting roles in several films such as Valentine's Day (2010) and The Giver (2014). In 2015, Swift became the youngest woman ever to be included on the Forbes "100 Most Powerful Women" list, ranking at number 64 (Gordon, 2017). This study is aimed to investigate the types of deixis in the song lyrics by Taylor Swift's Folklore album and to shed on the meanings of the use of deixis in those songs.

\section{LITERATURE REVIEW}

\section{Diexis}

Deixis is derived from the Greek word means "pointing language" (Yule, 1996). Deictic expressions are divided into two: proximal and distal terms. Proximal terms are known near the speaker; the terms are this, here, now. Whereas distal term is known away from the speaker, it includes that, there and then. Thus, deixis is a signifier used for identifying people, object, event, process, or an activity that is being spoken or referred. 
Levinson (1983) states deixis is a way to observe how relationship between language and context is reflected in the structures of languages. Meyer (2009) also claims that words have a pointing function, commonly referred to deixis. The function of deixis is to point and identify persons, objects, events, processes, etc. It is also related to using a particular linguistic referring device, such as demonstrative - for example, this pencil, that person, these books, those children. From the definition above, the writer can conclude that deixis is part of speech, which is the most obvious way to describe the relationship between language and context in the structure of language itself. Despite the fact they are common, deictical expressions such as such as here, there, this or that, now and then, today or tomorrow, yesterday, you, me, her, him, it, her, I, them, etc. cannot be directly understood if the listeners do not know the context.

\section{Types of Deixis}

Each linguist has its opinion and view about types of deixis. Levinson (1983) mentions three types of person deixis: first- person, second-person, and third person. Person deixis refers to the speaker who is currently speaking in the utterance, represents the speaker and reference. Meanwhile, time deixis concerns with the particular times involved in and referred to in an utterance. Levinson (1983) states if time deixis affects the encoding of temporal points and spans relative to when an utterance is spoken (or written message inscribed). It means that time deixis is the references that it is used to state the time when the utterance is uttered: present tense, future tense, and past tense. Moreover, according to Levinson (1983), spatial deixis concerns the encoding of spatial locations relative to the participants' location in the speech event. The function is to indicate the place. In English, the near speaker or proximal terms are here, this, these. The away from the speaker or distal terms are such as that, there, those. Proximal terms are typically interpreted in terms of the speaker's location or the deictic center. Distal terms can indicate "away from the speaker," but in some languages can be used to distinguish between "near addressee" and "away from both speaker and addressee."

Discourse deixis refers to text deixis. According to Levinson (1983), discourse or text deixis is an expression used to refer to particular discourse that contains the utterance or as a signal and its relations to the surrounding text. Discourse is a deictic reference to a portion of a discourse relative to the speaker's current location in the discourse. The deictic word used here is the demonstratives this and that. This can refer to a portion of the discourse, and that can be used to a previous portion. The word that is referred to the performance which needs no further explanation.

Social deixis concerns the social information encoded within various expressions, such as relative social status and familiarity. According to Levinson (1983), social deixis refers to the social characteristics of or distinctions between the participants or referents in a speech event. The function of social deixis is to distinguish social status. Besides, social deixis is a reference to the social characteristics of, or distinctions between, the participants or referents in a speech event. Social deixis 
relates to the social distinction and participant who has a role. Social deixis consists of relational social deixis and absolute social deixis. Social deixis is a deictic reference to referent social characteristics apart from any relative ranking of referents or deictic reference to a social relationship between the speaker and addressee. For example, my husband, teacher, cousin, and pronouns (you, her). The second is absolute social deixis. Absolute social deixis is a deictic reference that is usually expressed in certain forms of address, including no comparison of the speaker and the hearer's ranking. For example, your highness, your majesty, Mr. President, etc.

\section{METHOD}

\section{Design and Samples}

This research is qualitative research employing a descriptive method. The writer studies deixis in song lyrics from the selected song in Taylor Swift's Folklore album. Folklore is the eighth album by an American singer and writer, Taylor Swift, released on July 24, 2020. In analysing song lyrics, the writers select five songs among sixteen songs in the album: Cardigan, the Last Great American Dynasty, August, Illicit Affairs, and Betty.

\section{Instrument and Procedures}

This study analysed the types of deixis in the selected songs of Taylor Swift's Folklore album and how the use of deixis in its lyrics helps Taylor Swift deliver her message. The writer analysed the data based on theories by Levinson (1983) and Yule (1997). Eventually, the writer presented the resulting analysis in the form of a figure (lyrics) with a verbal description.

\section{Data Analysis}

For data analysis, the writers make transcription based on the samples of the songs. Next, applying coding techniques in order to classify the themes based on Levinson (1983) theory is conducted. To achieve reliable interpretation of the data, triangulation techniques has been applied by consulting with the theory and All the data are gathered and categorized, the writers analysed and interpret the data. The writers describe the types of deixis based on the proof by looking at the counted frequency.

\section{RESULTS AND DISCUSSION}

\section{Types of Deixis}

This study has found that the songs composed by Tailor Swift use various types of person deixis. However, the dominant use of the first-person deixis in the "cardigan" song helps Taylor Swift as the songwriter tell a story where she 
positions herself as the main character. According to Levinson (1983), first-person deixis refers to the person currently speaking in the utterance. When using deictical expressions such as $I$ and $m e$, Taylor intends to refer to herself as the main character of the story depicted through the songs. Taylor Swift intends to convey her message to the hearers. In so doing the hearers will easily identify the message behind its lyrics. They learn about who is speaking through the song. Amaliyah (2017) notes that using person deixis makes it easy to describe personal pronouns. They connect the utterance with time and place. The detailed explanation is presented in the following section:

Table. 1 Person Deixis in Taylor Swift's songs

\begin{tabular}{|c|c|c|c|c|c|c|}
\hline \multirow[b]{3}{*}{ Song } & \multicolumn{6}{|c|}{ Person } \\
\hline & \multicolumn{2}{|c|}{ First Person } & \multicolumn{2}{|c|}{ Second Person } & \multicolumn{2}{|c|}{ Third Person } \\
\hline & Singular & $\begin{array}{l}\text { Plural } \\
\text { (Freq }\end{array}$ & Singular & $\begin{array}{l}\text { Plural } \\
\text { (Freq }\end{array}$ & Singular & $\begin{array}{l}\text { Plural } \\
\text { (Freq }\end{array}$ \\
\hline "cardigan" & $52 \%$ & $1 \%$ & $42 \%$ & $0 \%$ & $0 \%$ & $5 \%$ \\
\hline \multicolumn{7}{|l|}{ "the last } \\
\hline "august" & $61 \%$ & $11 \%$ & $28 \%$ & $0 \%$ & $0 \%$ & $0 \%$ \\
\hline "illicit & $31 \%$ & $0 \%$ & $51 \%$ & $0 \%$ & $4 \%$ & $14 \%$ \\
\hline "betty" & $54 \%$ & $0 \%$ & $40 \%$ & $0 \%$ & $6 \%$ & $0 \%$ \\
\hline
\end{tabular}

Regarding time deixis, Taylor Swift mostly uses past- time deixis in her songs in this album. The uses of past-time deixis in this album represent the album title itself, Folklore. Ratna (2014) argues that time deixis indicates when that moment happens between the songwriter and hearer. Without its use, the listener will not notice when the time is, and it will be hard then to find the message in the lyrics.

Table 2. Time Deixis Classification

\begin{tabular}{|c|c|c|c|}
\hline \multirow{2}{*}{ Songs } & \multicolumn{3}{|c|}{ Time Deixis } \\
\cline { 2 - 4 } & $\begin{array}{c}\text { Present } \\
(\text { Freq \%) }\end{array}$ & $\begin{array}{c}\text { Future } \\
\text { (Freq \%) }\end{array}$ & $\begin{array}{c}\text { Past } \\
\text { (Freq \%) }\end{array}$ \\
\hline "cardigan" & $70 \%$ & $0 \%$ & $30 \%$ \\
\hline $\begin{array}{c}\text { "the last great american } \\
\text { dynasty" }\end{array}$ & $0 \%$ & $0 \%$ & $100 \%$ \\
\hline "august" & $0 \%$ & $0 \%$ & $100 \%$ \\
\hline "illicit affairs" & $0 \%$ & $0 \%$ & $100 \%$ \\
\hline "betty" & $50 \%$ & $0 \%$ & $50 \%$ \\
\hline
\end{tabular}

There are two kinds of time deixis in the "cardigan" song. The first is in the present time, and the second is in the past time. The deictic words found 
indicate the time deixis are: now (1), this long (1), and longest time (1). The use of time deixis in the "cardigan" song shows that Taylor Swift narrates the story in the present time. The story she tells has already happened in the past. In the "the last great American dynasty," "august," and "illicit affairs" songs, the writer finds the only used type of time deixis is past time deixis. In "the last great American dynasty," the deictic words found indicate the time deixis are: on the afternoon (1), at the midnight (1), and fifty years (1). The deictic words in the "august" song are: back when (1), a moment in time (1), and never (1). While in the "illicit affairs" song, the deictic word indicates the deixis is one single time (1). It indicates in which the story Taylor Swift represents is all happened in the past time. In the "betty" song, the writer finds the use of present-time deixis and past- time deixis. The deictic words are this time (1), now (1), one time (1), and those days (1). Their frequency is equal, which indicates that the story Taylor Swift sings occurred in the past, but she represents it in the present time.

The selected songs from the Folklore album also indicate the other type of deixis, which is spatial deixis that concerns of speaker's location. The proximal terms of spatial deixis are most used in the "cardigan" song. Levinson (1983) argues proximal terms are typically interpreted in terms of the speaker's location or the deictic center. In "cardigan," the writer finds the deictic words around (2). It indicates that the story in this song takes place near the speaker. Furthermore, in "the last great american dynasty," "august," "illicitaffairs," and "betty" songs, the writer finds that Taylor swift uses the distal terms of spatial deixis. According to Levinson, distal terms can indicate "away from the speaker," but in some languages can be used to distinguish between "near addressee" and "away from both speaker and addressee." In "the last great American dynasty," there are some deictic words such as there (5) and this (3). In "august," there is the deictic word away (6). In the "illicit affairs," the deictic word over (1) was also found. Finally, the deictic word from the far (1) in the "betty" song was also found. Those deictic words indicate if the story Taylor Swift sings is taking place far away from her.

Table 3. Spatial Deixis Classification

\begin{tabular}{|c|c|c|}
\hline \multirow{2}{*}{$\begin{array}{c}\text { Song } \\
\text { s }\end{array}$} & \multicolumn{2}{|c|}{ Spatial Deixis } \\
\cline { 2 - 3 } & $\begin{array}{c}\text { Distal Term } \\
(\text { Freq \%) }\end{array}$ & $\begin{array}{c}\text { Proximal Term } \\
\text { (Freq \%) }\end{array}$ \\
\hline "cardigan" & $0 \%$ & $100 \%$ \\
\hline $\begin{array}{c}\text { "the last great american } \\
\text { dynasty" }\end{array}$ & $60 \%$ & $40 \%$ \\
\hline "august" & $100 \%$ & $0 \%$ \\
\hline "illicit affairs" & $100 \%$ & $0 \%$ \\
\hline "betty" & $100 \%$ & $0 \%$ \\
\hline
\end{tabular}

Spatial deixis in the Folklore album makes it hearer easier to interpret where the song takes place. The writer believes Taylor Swift wants to tell her listener the 
place condition between the speaker and the hearer. As the findings have shown, it indicates that distal terms are the most used. Thus, the writer can conclude the story Taylor Swift sings is take place far away from her, that she, as the speaker and the hearer, are separated in two different places.

\title{
Meanings
}

After identifying the types of deixis and their intended use in the selected songs in Taylor Swift's Folklore, the writer reveals the reference message she delivers through her songs.

\section{"cardigan"}

From the title "cardigan," the writer infers it represents an ignored item that became a valuable asset someone can have. By the dominant use of the first-person deixis in its lyrics, Taylor Swift considers herself a naive yet valuable cardigan.

\section{[Verse 1]}

Vintage tee, brand new phone

High heels on cobblestones

When you are young, they assume you know nothing

Sequin smile, black lipstick

Sensual politics

When you are young, they assume you know nothing

Swift, 2020, track 2.

In the first verse section, Taylor Swift tries to recollect how she was used to feeling around her romantic interest. There was a moment when she knew she was falling in love with him. Taylor Swift was impressed with his appearance on a vintage tshirt and a brand-new phone. She was young at that moment, but she knew that it was love. That makes people around her stopped to put some worth on her words. Her political beliefs were laughed at, and people assume she knows nothing but love.

\author{
[Chorus] \\ - But $\underline{I}$ knew you \\ Dancin' in your Levi's \\ I knew you \\ Hand under my sweatshirt. \\ $\underline{\text { [Refrain] }}$ \\ And when $\underline{I}$ felt like $\underline{I}$ was an old cardigan \\ Under someone's bed

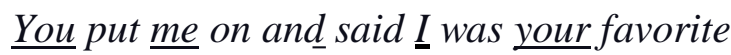

Swift, 2020, track 2. 
Despite not being appreciated at the time, Taylor Swift says in the chorus section that she knew this person. She likes everything about him, his jeans, his smile, his kisses. In the refrain section, Taylor Swift lets the hearer know that her happiness was tied to her romantic partner. She was like an old cardigan, which he would occasionally wear. She was a choice of his romantic interest, but he was everything for her. And that makes her immensely happy at that moment.

\title{
[Verse 2]
}

A friend to all is a friend to none

Chase two girls, lose the one

When you are young, they assume you know nothin'

Swift, 2020, track 2.

At the second verse section, Taylor Swift starts contemplating her life choices when she was young. She has understood that she was only an option for him. He could replace her with anyone. Taylor Swift was sincerely tried to impress him. However, as she showed interest in him, she was of less value to him. He would instead pursue someone more of a challenge, which sadly was not her.
[Bridge]
..Was all we needed

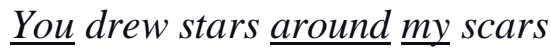
But now I'm bleedin'

Swift, 2020, track 2.

As in the second verse section, she once again understands that she was perceived as someone with less value. All she wanted was his kiss. However, while she was wounded, her romantic interest only cut the wound deeper. As the song goes further, Taylor Swift realizes that her feeling will only hurt her more. That is why she tries to put herself first. Although she knew he would come back to her when his interest in others dies. As she says in the third verse section:

\author{
[Verse 3] \\ - But I knew you'd linger like a tattoo kiss \\ I knew you'd haunt all of $\underline{\text { my }}$ what-ifs \\ .. 'Cause I knew everything when $\underline{I}$ was young \\ I knew I'd curse you for the longest time \\ ..I knew you'd miss me once the thrill expired \\ And you'd be standin' in my front porch light \\ And $\underline{I}$ knew you'd come back to $\underline{\text { me }}$ \\ You'd come back to me
}

Swift, 2020, track 2.

After interpreting the story behind its lyrics, the writer believes that the reference message Taylor Swift delivers is to all teenagers who are innocent and know little about love. The message indicates as a reminder that the pain of losing someone you loved is heartbreak at any age. It shows the pain of a first heartbreak from Taylor Swift's perspective, who is adult and mature, which, by doing so, gives 
respect to young love and pain. The way Taylor Swift represents this song using the past tense is also helpful to catch other messages. It indicates that even though the pain is heart-wrenching, it can eventually be left in the past, and become a memory, even if it is painful.

\section{"the last great american dynasty"}

From the title "the last great american dynasty," the writer infers the song is about a person's story. By the dominant use of the third person deixis, the writer believes that Taylor Swift, through her perspective, is the one who is telling the story.

[Verse 1]

Rebekah rode up on the afternoon train, it was sunny

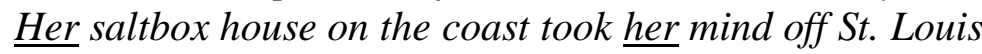

Bill was the heir to the Standard Oil name, and money

..There's only so far new money goes

They picked out a home and called it "Holiday House"

Their parties were tasteful, if a little loud

The doctor had told him to settle down

It must have been her fault his heart gave out

Swift, 2020, track 3.

In the first verse section, it has shown right away that Taylor Swift is telling a story of a person named Rebekah, who is moving from St. Louis to the saltbox house and marry Bill. Through Taylor Swift's perspective, her listener could picture the wedding of Rebekah and Bill. It was charming but a little gauche. However, the town and the people do not seem to like Rebekah, as Taylor Swift says, "The doctor had told him to settle down. It must have been her fault his heart gave out."

\section{[Chorus]}

And they said "There goes the last great American dynasty"

Who knows, if she never showed up what could've been

There goes the maddest woman this town has ever seen

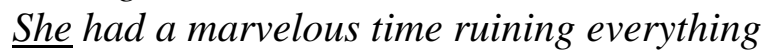

[Verse 2]

Rebekah gave up on the Rhode Island set forever.

Swift, 2020, track 3.

From the chorus section, Taylor Swift says that the town believes if Rebekah has ruined everything. They even called her the maddest woman this town has ever seen. Rebekah thus chooses to give up and live her own life. As Taylor Swift tells in the second verse, she is embracing the hatred of her by money and luxurious pleasures.

[Bridge]

Fifty years is a long time

Holiday House sat quietly on that beach

Free of women with madness 


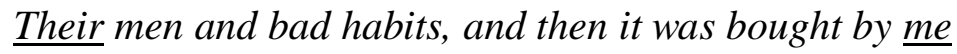
[Chorus]

Who knows, if I never showed up what could've been There goes the loudest woman this town has ever seen I had a marvelous time ruining everything

Swift, 2020, track 3.

In the bridge section, Taylor Swift eventually reveals her Holiday House purchase after fifty years of its vacancy. She thus shifts the lyrics to the first-person narrative, claiming herself as the loudest woman the town has ever seen. After analyzing the lyrics, the writer assumes the reference message of this song is Taylor Swift herself. Besides representing the story of Rebekah, she also wants to relate herself to her. At the beginning of the song, Taylor Swift tells us that Rebekah has become a target of hatred from people around her. But in the end, Taylor Swift sings about herself. She reflects on the mass criticism she receives with Rebekah's story.

\section{"august"}

From the title "august," the writer infers it represents a specific romance theme during the summer. By the dominant use of the first-person deixis, the story in its lyrics was told by Taylor Swift as if she is the main character.

[Verse 1]

Salt air, and the rust on your door

I never needed anything more

Whispers of "Are you sure?"

"Never have I ever before"

[Chorus]

_ But $\underline{I}$ can see $\underline{\text { us }}$ lost ...

- And $\underline{I}$ can see $\underline{\text { us }}$ twisted in bedsheets

..'Cause you were never mine

Swift, 2020, track 8 .

In the first verse section, Taylor Swift narrates a scene between herself and her love interest. As the dialogue there suggests, the writer assumes something just more than an intimate scene has taken place. Furthermore, by the song's chorus, Taylor Swift says that it is all a memory now. The memories all passed on just like August month did and never returned because he was never hers. More memories haunt her mind. Taylor Swift wonders if he would call her when they are back at school, as the second verse says. However, she feels foolish to have thought that there ever was an "us" just because they had an intimate scene. She tries to embrace the reality that he was not hers to lose. Take a look at the second verse and outro section:

[Verse 2]

Your back beneath the sun 
Wishin' I could write $\underline{\text { my name on it }}$ Will you call when you're back at school?

I remember thinkin' I had you

[Outro]

But do you remember?

Remember when I pulled up and said, "Get in the car"

.."Meet me behind the mall"

Remember when I pulled up and said, "Get in the car.."

Swift, 2020, track 8.

"august" is another bittersweet song similar to "cardigan". The story of its song has a reference message. Taylor Swift examines what it is like to lose someone that was never really yours. It shows how something can be lost without you being a part of it. However, there is a reminder that love, conflicts, and breakups will be lost with time.

\title{
"illicit affairs"
}

Based on the title "illicit affairs," the writer infers it represents a story of reminiscing a relationship that was kept a secret.

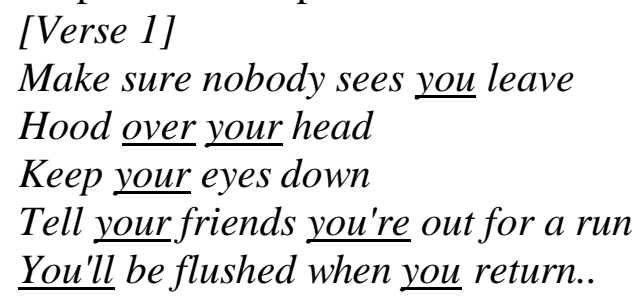

Swift, 2020, track 10.

In the first verse of the song, Taylor Swift describes how this person sneaks in and out, wears hoodies, meets in parking lots, and lies to his close friends. He even has to take a road less traveled by people to minimize the risk of running into somebody on his way back.

\author{
[Chorus] \\ And that's the thing about illicit affairs \\ And clandestine meetings \\ And longing stares \\ It's born from just one single glance \\ But it dies, and it dies, and it dies \\ A million little times
}

Swift, 2020, track 10.

By the chorus, Taylor Swift knows if that was the nature of an illicit affair. There is no love and affection for each other. It just all physical and fulfilling human needs. That kind of relationship was born from a stare, and it will be dying on and on. 


\author{
[Verse 2] \\ Leave the perfume on the shelf \\ That you picked out just for him \\ So you leave no trace behind \\ ... $\underline{\text { You }}$ showed me colors you know \\ I can't see with anyone else \\ Don't call me kid \\ Don't call me baby \\ ..A million little times
}

Swift, 2020, track 10.

In the second verse, Taylor Swift highlights how these affairs are deceiving people around him. However, in the bridge section, Taylor Swift seems to be involved with this person. She realizes her follies and the emotional confusion as to the result of this affair. Even though Taylor Swift feels upset at him, she believes that they have shared a bond no one else can create. Hence, she chooses to ruin herself to be with him. This song has the reference message on illegitimate love affairs' craziness, resulting in a depth of pain. The writer assumes if Taylor Swift wants to show how an affair could break someone's self-worth, how it was deceiving yourself too only to realize that you may be addicted and cannot leave it that easily.

\title{
"betty"
}

By the title "betty", the writer infers it represents Betty, a girl whom Taylor Swift wants to tell a story on.

\author{
[Verse 1] \\ Betty, I won't make assumptions \\ About why you switched your homeroom \\ But, $\underline{I}$ think it's 'cause of $\underline{m e}$ \\ Betty, one time $\underline{I}$ was riding on $\underline{\text { my skateboard }}$ \\ When I passed your house \\ It's like I couldn't breathe \\ [Pre-Chorus] \\ You heard the rumors from Inez. \\ You can't believe a word she says \\ Most times, but this time, it was true \\ The worst thing that I ever did \\ Was what I did to you
}

Swift, 2020, track 14 .

In the first verse and pre-chorus section, Taylor Swift talks about Betty, who moved out of her homeroom. Although Taylor Swift does not want to believe it, she thinks it because of her. She knows it must be Inez who starts the rumors, but this time it was not a rumor. It was the truth. 
[Chorus]

But if I just showed up at your party

Would you have me? Would you want me?

Would you tell me to go fuck myself

...I'm only 17, I don't know anything

But $\underline{I}$ know I miss you

[Verse 2]

Betty, $\underline{I}$ know where it all went wrong

Your favourite song was playing

...I hate the crowds, you know that

Plus, $\underline{I}$ saw you dance with him

Swift, 2020, track 14.

Whatever Taylor Swift has done, it seems that Betty is mad at her. As the chorus says, Betty is avoiding Taylor Swift so much. She admits it because she is only seventeen that she was naive and stupid. But then Taylor Swift narrates if she sees how the affair happened. It was at the party, and Betty was dancing with a guy to her favorite song.

\author{
[Bridge] \\ I was walking home on broken cobblestones \\ Just thinking of you \\ When she pulled up \\ Like a figment of $\underline{m y}$ worst intentions \\ She said, "James, get in, let's drive" \\ Those days turned into nights \\ Slept next to her, but \\ I dreamt of you all summer long
}

Swift, 2020, track 14.

After Taylor Swift sees the affair, in the bridge section, she says that she walks home on "broken cobblestones", which the writer assumes is a metaphor for pain from the mistakes she committed. The worst is when Betty drives by her and offers to give her a ride to her, as the dialogue in the lyrics goes; "She said, "James, get in, let's drive."

[Verse 3]

Betty, I'm here on your doorstep

And I planned it out for weeks now

But it's finally sinking in

Betty, right now is the last time

I can dream about what happens

When you see my face again

[Pre-Chorus] 
The only thing $\underline{I}$ wanna do

...Yeah, $\underline{I}$ showed up at your party

Swift, 2020, track 14 .

In the third verse and pre-chorus, the only thing Taylor Swift wants to do is apologize to Betty. She has planned it for weeks, and now she does show up at Betty's party. Back to the chorus section, a lot of emotions start running through Taylor Swift's head. What would happen when she finally faces her? Would she chase her out? Or would she kiss her? Taylor Swift examines a story where she has lost the love of her life and does not understand how to get it back. By this song, the writer notices if everybody makes mistakes, everybody messes up something. These situations happen in our lives. Thus, Taylor Swift's reference message is that she wants to remind the hearer if there is a moment where we need to learn how to give apology.

\section{CONCLUSION}

Numbers of deixis have been found in song lyrics of Taylor Swift's Folklore album: person deixis, time deixis, and spatial deixis. Taylor Swift often uses deictic words such as I and me, which refers to herself. In Folklore album, the time deixis is represented in the specific time, such as in the present time, past time, and future time. Taylor Swift intends to tell a story that has happened both in the past and in the present time. Furthermore, some proximal expressions of spatial deixis is also notified such as here, this, and these. The songs of Taylor Swift sings depict distant feelings and spatial distance that separate her from her beloved one. The use of person deixis has been extensively used in the sons with a purpose that Taylor Swift intends to share her own personal views. Experiencing songs from Taylor Swift finally brings an understanding of the reflection of life experiences from adolescence as a part of society. The analysis deixis of this study reveals a variety of life issues is treated directly or is strongly involved in the content of the lyrics of songs like love, lack of love or sex. These themes are intense during adolescence. An adolescent's view of himself or herself may be related to previous musical experiences, social interactions, school, culture, and previous life experiences. Musical preference, which is often part of an adolescent's identity, often changes with age, mood, social status, or many other circumstances that are constantly changing. This study found that lyrics have undergone dramatic changes when the influence of other cultures is unavoidable. Western songs including the composition of Taylor Swift need to be treated with caution. As with other types of music, some lyrics contain vulgarism. Over the last few decades, the lyrics like reggaeton music have become increasingly explicit, especially with regard to sex, gender discrimination and violence. In some cases, song lyrics convey potentially negative messages in which the female sex is treated as inferior and submissive. Such lyrics are of particular concern in the current environment as they pose serious and authentic threats to social relations among adolescents. Thus, these are the biggest consumers of this music style. This is an issue of significant interest and concern for parents and educators. 


\section{REFFERENCES}

Amaliyah, I. (2017). A Pragmatics Study on Deixis Analysis in the Song Lyrics of Harris J's Salam Album Song. 141.

Bull, V. (2011). Oxford: Learner's Pocket Dictionary - ed. 4. Oxford University Press Inc.

Campo, S. S. (2020). An Approach to Reggaeton's Songs: A Co-Educational and Pedagogical Proposal with Teenagers. International Education Studies, 13(7), 12-19.

Cruse, A. (2006). Glossary of Semantics and Pragmatics Glossaries in Linguistics EUP. Edinburgh University Press, 2006.

Evans, P., \& Schubert, E. (2008). Relationships between expressed and felt emotions in music. Musicae Sci, 12(1), 75-99.

Gabrielsson, A. (2011). Strong experiences with music: Music is much more than just music. . Oxford: Oxford University Press.

Gordon, J. (2017, August 30). This Is Who Every Taylor Swift Song Is About. Retrieved from spin: https://www.spin.com/featured/taylor-swift-songsexplanation-guide/

Hamm, F., \& Zimmermann, T. E. (2002). Semantics, Volume 2; Volume 10 of Linguistische Berichte. Helmut Buske.

Hidayah, A. (2019). A Deixis Analysis of Song Lyrics in Back To You By Selena Gomes.

Huang, Y. (2012). The Oxford Dictionary of Pragmatics. OUP Oxford.

Juslin, P., N. (2011). Music and emotion: Seven questions, seven answers, in music and the mind. . Oxford: Oxford University Press.

Levinson, S., C. (1983). Pragmatics Cambridge Textbooks in Linguistics. Textbooks in linguistics (illustrate). Cambridge University Press.

Meyer, C., F. (2009). Introducing English Linguistics Cambridge Introductions to Language and Linguistics. Cambridge University Press.

Miranda, D. (2012). The role of music in adolescent development: Much more than 
the same old song. Taylor\&Francis Online, 18(1), 5-22.

Natalia, Y., \& Santoso, I. (2020). Person Deixis and Spatial Deixis of King Dangdut By Rhoma Irama Songs. 3.

Oriola, S., \& Gustems, J. (2015). Música y adolescencia: usos, funciones y consideraciones educativas. Universitas Tarraconensis, 2(1), 27-42.

Ratna, D. (2014). A Deixis Analysis of Song Lyrics in Taylor Swift "Red” Album. 84.

Ruud, E. (2013). Can music serve as a "cultural immunogen"? An explorative study. International Journal of Qualitative Studies on Health and WellBeing, 8(1), 15-35

Horn, L., R \& Ward, G. (2004). The Handbook of Pragmatics NY: Blackwell Publishing Ltd

Sapir, E. (1921). Language: An Introduction to the Study of Speech.

Sitorus, E. (2019). A Deixis Analysis of Song Lyrics in Calum Scott "You Are the Reason." The Editors of Encyclopedia Britannica. (n.d.). Song. Retrieved January 17, 2021, from https://www.britannica.com/art/song

Yule, G. (1996). Pragmatics. NY: Routledge .

Yule, G. (1997). Referential Communication Tasks. NY: Routledge. 